\title{
EXPERIMENTAL INVESTIGATION ON CONCRETE BY REPLACING CRUSHER DUST AS FINE AGGREGATE AND GRANITE CHIPS AS COARSE AGGREGATE
}

\author{
K. Hanumanthu ${ }^{1}$, SS.Manugula ${ }^{2}$, Prathik Kulkarni ${ }^{3}$ \\ ${ }^{1,3}$ Assistant Professor, Department of Civil Engineering, GNITC, Telangana, India \\ ${ }^{2}$ Professor, Department of Civil Engineering, GNITC, Telangana, India
}

\begin{abstract}
In this present work we identified and investigated the use of crusher dust and granite floor slab chips in concrete as an alternative fine aggregate and coarse aggregate respectively, the tests were conducted on standard concrete cubes (150 mm x 150 $m m \times 150 \mathrm{~mm})$, cylinders $(150 \mathrm{~mm} \times 300 \mathrm{~mm})$ and prisms $(100 \mathrm{~mm} \times 100 \mathrm{~mm} \times 500 \mathrm{~mm})$. Tests on the physical properties of crusher dust, granite chips and its influence on the strength of fresh and hardened state, along with a comparative study with the concrete of river sand are made. The properties investigated were specific gravity, fineness modulus, water absorption, free surface moisture, bulk density and grading zone. Tests were conducted on 6 cubes, 6 cylinders and 6 prisms for M20 grade mix design with sand and crusher dust as fine aggregates, granite metal and granite floor slab chips as coarse aggregates. The strength parameters compressive strength. Split-Tensile strength and flexural strength were compared at 7 days and 28 days respectively. Mix design procedure in accordance with IS 10262-2009, IS 456-2000 and Sp 23-1982 using 20mm coarse aggregate was adopted for investigation. The investigation indicates that crushed stone dust has vast potential as fine aggregate in concrete construction. Crusher dust not only reduces the cost of construction but also helps reduce the impact on environment by consuming the material hitherto considered as a waste product with few applications.
\end{abstract}

Keywords: Crusher Dust, Granite Floor Slab Chips, Concrete Mix.

\section{INTRODUCTION}

The new technologies and processes were appearing from construction industry to economize, expedite and stream line the work process. There will be many differences seen in manufacturing process of concrete in accordance with the requirements of the structure say for example by utilizing new admixtures and the traditional materials. The cost of construction will tremendously increasing from 60 to 70 percent since due to utilizing of building materials like cement, steel, concrete and timber. In addition to this the cost of construction will be again rise nearly 15 to 18 percent in day to day life due to cost of materials. There is a great need to improve the manufacturing process of concrete and optimum quantity of utilization of its ingredients because more changes that are taking place in environment, economy and quality control.

Concrete is a heterogeneous material consisting of cement, fine aggregate and coarse aggregates. To meet requirements we can utilize alternative materials for coarse and fine aggregates such as crushed stones (Granite and Basalt as ingredients) of desirable sizes and river sand as fine aggregates in conventional concrete. While preparing mortar and concrete it will be more economical of using locally available materials as an alternative for fine aggregates rather than usage of river sand. Stone dust is one of the materials which is found abundantly from crusher units. By using crushed stone dust as an alternative for replacing fine aggregate. It not only reduces the cost of construction but also provides a solution for the disposal problem of stone dust, at the same time it avoids the stone dusts waste impact on environment.

\subsection{Research Significance}

Usually while making concrete and motor river sand is used as a fine aggregate, this is available from long distances. Furthermore, this causes dwindling resources and escalating costs of construction materials in manufacturing concrete. Hence it is necessary to find alternative material for river sand to fulfill the lack of fine aggregate in making concrete. In the place of river sand crusher stone dust is found to be best suitable material to produce concrete mixes. During crushing of granite or basalt stones, in order to produce coarse aggregate, the crushed stone waste will be available abundantly as a by-product. From this, it's an innovative way of receding waste materials instead of dumping into discarded areas. The main aim of this project is to explore the properties and the right choice to use stone dust in the formation of concrete. In addition, to this it's also found, that the characteristic strength of concrete for 28 days, the spilt tensile strength and flexural tensile strength will be more with crusher stone dust compared to river sand, When it is used as a fine aggregate in making concrete. In case of reinforced concrete researchers has been observed that the crusher stone dust will have good prospects and economical rather than utilizing river sand in repairing concrete. 


\subsection{Summary}

To achieve the economy, the construction industries are struggling more to bring out various methods in order to have the best quality of concrete. Among those materials crusher stone dust is one of the materials to replace river sand as an alternative for fine aggregate. By utilizing the crusher stone dust it will be serves as ecofriendly materials as well as economical in making concrete. The forms of crusher stone dust by disintegration are enormously used in production of mortar \& concrete.

\section{EXPERIMENTAL PROGRAMME}

\subsection{Materials}

The materials which are used in this present research work are ordinary Portland cement 53 grade, River, crusher dust and crushed granite aggregate of $20 \mathrm{~mm}$ nominal size and crushed granite floor slab chips of $20 \mathrm{~mm}$ of nominal size.

\subsection{Cement}

For casting the specimens such as cube, cylinder and beams, the ordinary Portland cement of 53 grades is used. Table 1 reveals the physical properties of cement.

\subsection{Fine Aggregates}

River sand and crushed stone dust has been used as fine aggregate in concrete. Table 2 presents the physical properties of fine aggregates.

\subsection{Coarse Aggregate}

Crushed granite aggregate and granite floor slab chips of 20 $\mathrm{mm}$ nominal size was used as coarse aggregate for concrete. The test results for physical properties of coarse aggregate are presented in Table 3.

Table 1: Physical Properties of Cement

\begin{tabular}{|l|c|}
\hline \multicolumn{1}{|c|}{ Test } & 53 Grade \\
\hline Fineness & 10.6 \\
Specific gravity & 3.15 \\
Normal consistency & 31 percent \\
Setting time & 33 minutes \\
a) Initial setting time & 130 minutes \\
b) Final setting time & $2.1 \mathrm{~mm}$ \\
Soundness (Le Chatlier) & $53.66 \mathrm{Mpa}$ \\
Compressive strength at 28 Days & \\
\hline
\end{tabular}

Table 2: Physical Properties of Fine Aggregates

\begin{tabular}{|l|c|c|}
\hline \multicolumn{1}{|c|}{ Property } & River sand & Crusher dust \\
\hline Bulk density $\left(\mathrm{kg} / \mathrm{m}^{3}\right)$ & 1602.06 & 1742.5 \\
Specific gravity & 2.64 & 2.74 \\
Fineness modulus & 2.83 & 2.705 \\
Free surface & $0.329 \%$ & $1.06 \%$ \\
moisture & $1.987 \%$ & $1.86 \%$ \\
Water absorption & & \\
\hline
\end{tabular}

Table 3: Physical Properties of Coarse Aggregates

\begin{tabular}{|l|c|c|}
\hline \multicolumn{1}{|c|}{ Property } & $\begin{array}{c}\text { Granite } \\
\text { metal }\end{array}$ & $\begin{array}{c}\text { Granite } \\
\text { chips }\end{array}$ \\
\hline Max nominal size & $20 \mathrm{~mm}$ & $20 \mathrm{~mm}$ \\
Bulk density $\left(\mathrm{kg} / \mathrm{m}^{3}\right)$ & & \\
a) $\quad$ Loose state & 1562 & 1560 \\
b) Compacted state & 1686.7 & 1676.66 \\
Specific gravity & 2.595 & 3.07 \\
Fineness modulus & 8.38 & 7.85 \\
Free surface moisture & $0.258 \%$ & $0.184 \%$ \\
Water absorption & $0.918 \%$ & $1.15 \%$ \\
\hline
\end{tabular}

\subsection{Preparation of Specimens}

Four concrete mixes designated as $\mathrm{A}(1: 1.58: 2.77$, w/c $=$ $0.5), \mathrm{B}(1: 1.791: 2.77, \mathrm{w} / \mathrm{c}=0.5), \mathrm{C}(1: 1.58: 3.28, \mathrm{w} / \mathrm{c}=0.5)$ and $\mathrm{D}(1: 1.791: 3.28, \mathrm{w} / \mathrm{c}=0.5)$ were used in the investigations presented in this report.. Mix proportions for $\mathrm{A}, \mathrm{B}, \mathrm{C}$ and $\mathrm{D}$ are designed according to the principles of mix design of IS $10262-2009$ and SP $23-1982$ for M 20 grade concrete. The exact proportions of cement, sand, crusher stone dust and coarse aggregate were weighed accordingly as given in Table 4 and mixed thoroughly in the tray with water required quantities as per design calculations. The proportions for

- MIX A is designed with Granite metal and river sand as aggregates (here is referred to has conventional concrete).

- MIX B is designed with Granite metal and crusher dust as aggregates.

- $\quad$ MIX C is designed with Granite chips and River sand as aggregates.

- MIX D is designed with Granite chips and crusher dust.

Table 4: Mix proportions for plain concrete

\begin{tabular}{|c|c|c|c|c|}
\hline \multirow{2}{*}{ Material } & \multicolumn{4}{|c|}{ Mix designation } \\
\cline { 2 - 5 } & Mix A & Mix B & Mix C & Mix D \\
\hline $\begin{array}{c}\text { Cement ( } \\
\text { Kg/m3) }\end{array}$ & 394 & 394 & 394 & 394 \\
$\begin{array}{c}\text { River sand } \\
\text { (Kg/m3) }\end{array}$ & 622.46 & - & 622.46 & - \\
$\begin{array}{c}\text { Crusher } \\
\text { dust } \\
(\text { Kg/m3) }\end{array}$ & - & 705.933 & - & 705.933 \\
$\begin{array}{c}\text { Coarse } \\
\text { aggregate } \\
\text { Kg/m3) }\end{array}$ & - & - & 1293.89 & 1293.89 \\
$\begin{array}{c}\text { Granite } \\
\text { chips } \\
\text { (kg/m3) }\end{array}$ & 0.5 & 0.5 & 0.5 & 0.5 \\
$\begin{array}{c}\text { Water } \\
\text { cement } \\
\text { ratio }\end{array}$ & & & & \\
\hline
\end{tabular}




\subsection{Tests on concrete}

\subsubsection{Cubes tests}

For each Mix of concrete, six 150 x 150 x $150 \mathrm{~mm}$ cubes were cast and tested to determine the compressive strength, three at the age of 7days and the remaining three at the age of 28days. The results of the tests on cubes for compressive strength are presented in Table 5 for River sand, crusher dust, granite metal and granite chips and also comparison of average compressive strength for concrete with sand and crusher dust is shown in table 5 exhibits the compressive strength test conducted on cubes prepared with crusher dust and granite chips.

Table 5: Cube compressive strength of M20 Grade design mix (Average of 3 cubes), Corresponding graph shown in Fig 1

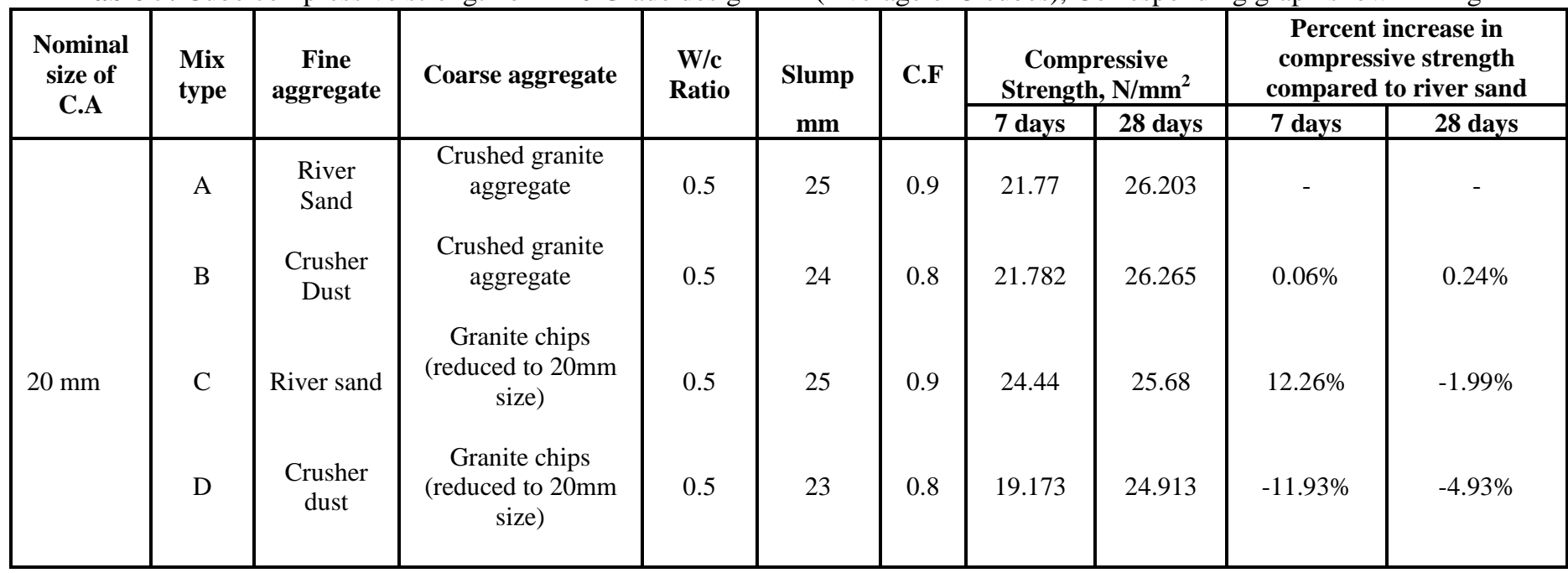

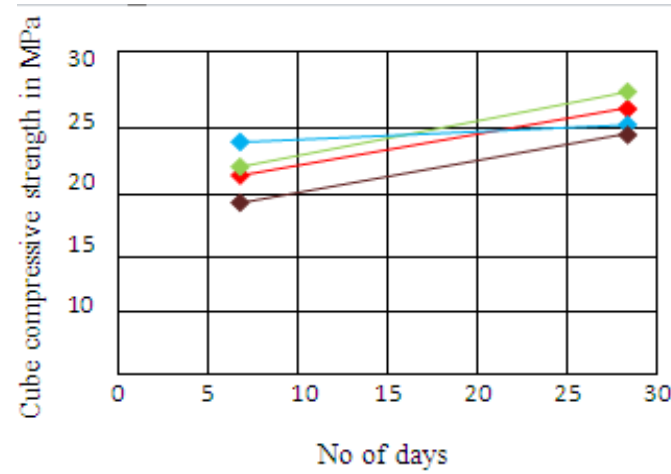

- Mix A

- Mix B

$\rightarrow$ Mix C

- Mix D

Fig 1: Cube compressive strength variation

\subsubsection{Split Tensile Tests}

Six $150 \mathrm{~mm}$ x $300 \mathrm{~mm}$ cylinder were cast and tested to determine the split tensile strength for each Mix; three cylinders were tested at the age of 7 days and the remaining three at the age of 28days. The test results for split tensile strength are presented in Table 6 for river sand and crusher dust, granite metal and granite chips respectively and also comparison of average split tensile strength for concrete with sand and crusher dust is shown in table 6 exhibits the split-tensile test conducted on cylinders prepared with crusher dust and granite chips.

Table 6: Split Tensile strength of M 20 Grade design mix (Average of 3 Cylinders), Corresponding graph shown in Fig 2

\begin{tabular}{|c|c|c|c|c|c|c|c|c|}
\hline \multirow{2}{*}{$\begin{array}{l}\text { Nominal } \\
\text { size of } \\
\text { C.A. }\end{array}$} & \multirow[t]{2}{*}{$\begin{array}{l}\text { Mix } \\
\text { type }\end{array}$} & \multirow[t]{2}{*}{ Fine aggregate } & \multirow[t]{2}{*}{ Coarse aggregate } & \multirow[t]{2}{*}{$\begin{array}{l}\text { W/c } \\
\text { Ratio }\end{array}$} & \multicolumn{2}{|c|}{$\begin{array}{c}\text { Tensile Strength, } \\
\text { N/mm }\end{array}$} & \multicolumn{2}{|c|}{$\begin{array}{l}\text { Percent increase in tensile } \\
\text { strength compared to river sand }\end{array}$} \\
\hline & & & & & 7 days & 28 days & 7 days & 28 days \\
\hline \multirow{4}{*}{$20 \mathrm{~mm}$} & A & River Sand & $\begin{array}{c}\text { Crushed granite } \\
\text { aggregate }\end{array}$ & 0.5 & 1.956 & 2.61 & - & - \\
\hline & B & Crusher Dust & $\begin{array}{l}\text { Crushed granite } \\
\text { aggregate }\end{array}$ & 0.5 & 2.12 & 2.748 & $8.38 \%$ & $5.28 \%$ \\
\hline & $\mathrm{C}$ & River sand & $\begin{array}{c}\text { Granite chips } \\
\text { (reduced to } 20 \mathrm{~mm} \\
\text { size) }\end{array}$ & 0.5 & 1.675 & 2.48 & $-14.36 \%$ & $-4.98 \%$ \\
\hline & $\mathrm{D}$ & Crusher dust & $\begin{array}{c}\text { Granite chips } \\
\text { (reduced to } 20 \mathrm{~mm} \\
\text { size) }\end{array}$ & 0.5 & 1.713 & 2.131 & $-12.42 \%$ & $-18.35 \%$ \\
\hline
\end{tabular}




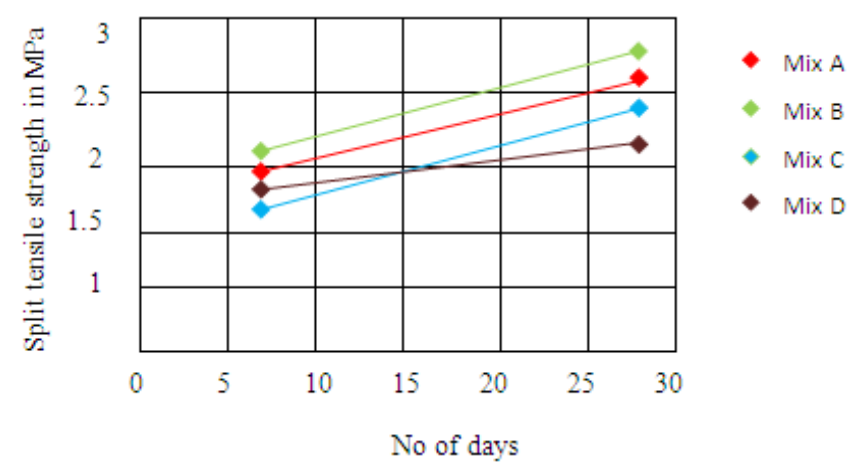

Fig 2: Split tensile strength variation

\subsubsection{Flexural Tensile Strength Test}

Six $100 \mathrm{mmx} 100 \mathrm{mmx} 500 \mathrm{~mm}$ size prisms were cast and tested in flexure for two - loading to determine the modulus of rupture, three at the age of 7 days and the remaining three at the age of 28 days. The test results for flexural tensile strength are presented in Table 7 for river sand, crusher dust, granite metal and granite chips, respectively and a comparison of average values for modulus of rupture for concrete with sand and crusher dust is shown in Table 7.

Table 7: Flexural Tensile strength of M 20 Graded design mix (Average of 3 prisms), Corresponding graph shown in Fig 3

\begin{tabular}{|c|c|c|c|c|c|c|c|c|}
\hline \multirow{2}{*}{$\begin{array}{c}\text { Nominal } \\
\text { size of } \\
\text { C.A. }\end{array}$} & \multirow{2}{*}{$\begin{array}{l}\text { Mix } \\
\text { type }\end{array}$} & \multirow{2}{*}{ Fine aggregate } & \multirow{2}{*}{ Coarse aggregate } & \multirow{2}{*}{$\begin{array}{l}\text { W/c } \\
\text { Ratio }\end{array}$} & \multicolumn{2}{|c|}{$\begin{array}{c}\text { Flexure Tensile } \\
\text { Strength, N/mm } \\
\end{array}$} & \multicolumn{2}{|c|}{$\begin{array}{l}\text { Percent increase in tensile } \\
\text { strength compared to river sand }\end{array}$} \\
\hline & & & & & 7 days & 28 days & 7 days & 28 days \\
\hline $20 \mathrm{~mm}$ & B & $\begin{array}{l}\text { River Sand } \\
\text { Crusher Dust } \\
\text { River sand } \\
\text { Crusher dust }\end{array}$ & $\begin{array}{l}\text { Crushed granite } \\
\text { aggregate } \\
\text { Crushed granite } \\
\text { aggregate } \\
\text { Granite chips } \\
\text { (reduced to } 20 \mathrm{~mm} \\
\text { size) } \\
\text { Granite chips } \\
\text { (reduced to } 20 \mathrm{~mm} \\
\text { size) }\end{array}$ & 0.5 & 3.94 & 5.473 & $+1.546 \%$ & $+0.484 \%$ \\
\hline
\end{tabular}

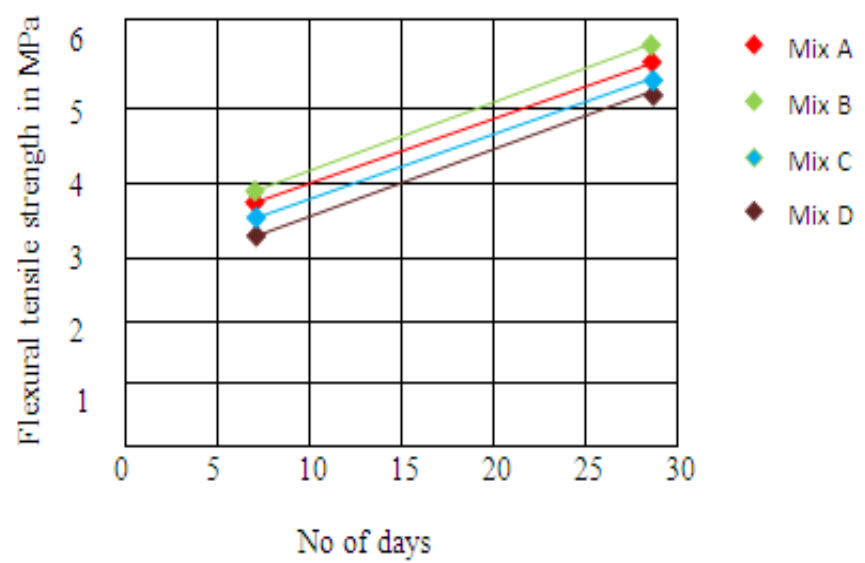

Fig 3: Flexural tensile strength variation

\section{RESULTS AND DISCUSSIONS}

The test results for physical properties of cement, fine and coarse aggregates are shown in Tables 1, 2 and 3. The proportions for design mix A, Mix B, Mix C and Mix D are shown in Table 4 . The mean values of cube compressive strength are presented in tables 5, the mean values of spilt tensile strength are presented in table 6 and the mean values of modulus of rupture are presented in table 7 .

\subsection{Discussions}

The physical properties, the workability and strength characteristics in compression, tension and modulus of rupture strength for M20 Grade concrete with sand and crusher dust as a fine aggregate and metal on $20 \mathrm{~mm}$ Granite metal and crushed granite chips are sustained and discussed.

\subsection{Crusher Dust As Fine Aggregate}

Table 2 shows the results of tests for physical properties of fine aggregates. Fineness modulus for river sand crusher dust was found as 2.83 and 2.705 , respectively. It indicates that crusher dust contains less percent finer particles compared to river sand. The sieve analyses on samples of fine aggregate shows that river sand and crusher dust belongs to same grading zone in many cases. The principles of mix design applied for concrete with crusher dust are same as those applied for river sand. On experimental investigation, it was found mortar and concrete prepared with crusher stone dust were relatively less workable than those prepared with sand. The increase in specific surface area for crusher dust due to the presence of high percent finer particles lead to high demand of water. The combined action of cement and stone dust produced a harsh concrete mix that lead for less consumption of cement. Previous investigations showed that the workability of mix prepared 
with crushed stone dust can best be improved by the addition of appropriate quantities of super plasticizers without affecting the strength of mix.

\subsection{Summary}

The use of crusher dust in plain concrete is most economical and there is no hesitation in using stone dust as fine aggregate for reinforced concrete where in its use is recommended. Use of granite chips as coarse aggregate for conventional concrete is scarily recommended for concrete as chips has no complete texture and angularly for making concrete.

\section{CONCLUSIONS}

Based on the experimental investigations the following conclusions can be concluded they are

- The crushed stone dust provides the strength to the concrete mix. There will be strong bonding between the crushed stone dust and ultra-fine particles due to roughness of crushed stone dust particles. The conventional concrete will be more permeable and durable than the concrete with crushed stone dust.

- When compared with conventional concrete, the concrete made with crushed stone dust will have increase in the compressive strength nearly of about $0.236 \%$ for concrete. The tensile strength of concrete nearly increases of about $5.28 \%$, in flexural strength nearly of about $0.484 \%$ when concrete made with crushed stone dust as fine aggregate.

- To achieve strength and economy the crushed stone dust will be useful in plain concrete beams and also reduces its impact on environment.

\section{REFERENCES}

[1]. Giridhar Kumar.V., Strength characteristics of concrete with crusher stone dust as fine aggregate M.E.Theries December 2003.

[2]. Nagaraj, T.S., and Zahida Banu., 'Efficient utilization of rock dust and pebbles as aggregate in Portland cement concrete', The Indian concrete journal,Vol.70,No.8, August 1996,pp.1-4.

[3]. Sahu, A.K., Sunil Kumar, and Sachan, A.K., 'Crushed stone waste as fine aggregate for concrete', The Indian concrete journal, January 2003.

[4]. Misra, V.N., 'Use of stone dust from crushers in cement-sand mortars', the Indian concrete journal, August 1984, pp.219-223.

[5]. Dr. A.D. Pofale Syed Raziuddin Quadri 'Effective Utilization of Crusher Dust in Concrete Using Portland Pozzolana Cement' International Journal of Scientific and Research Publications, Volume 3, Issue 8, August 2013.

[6]. Radhikesh P. Nanda , Amiya K. Das, Moharana.N.C 3 'Stone crusher dust as a fine aggregate in Concrete for paving blocks'.

[7]. Er. Lakhan Nagpal, Arvind Dewangan, Er. Sandeep Dhiman, Er. Sumit Kumar 'Evaluation of Strength Characteristics of Concrete Using Crushed Stone Dust as Fine Aggregate'.
[8]. Dhanasri K, Kishore Kumar M. 'Performance of Concrete by replacing Coarse Aggregate and Fine Aggregate with Blast Furnace Slag and Crusher Dust, International Journal of Innovative Research in Science, Engineering and Technology,

[9]. N. Mahendrana and K. Nagamanib. 'Strength and durability properties of concrete containing quarry rock dust as Fine aggregate'. R. ARPN Journal of Engineering and Applied Sciences.

\section{CODES OF PRACTICE}

The following are the codes used in this work.

- IS456-2000, "Indian standard code of practice for plain and reinforced concrete" fourth revision, BIS, New Delhi.

- IS 10262-2009,"recommended guidelines for concrete mix design", BIS, New Delhi.

- IS383-1970,'”ndian standard specifications for coarse and fine aggregate from natural source for concrete " 2 nd Edition, BIS, and New Delhi.

- SP 23-1982,"Hand book on concrete mixes" BIS, New Delhi.

\section{BIOGRAPHIES}

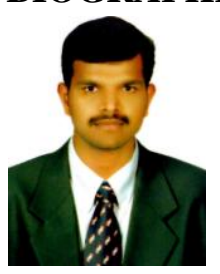

K. Hanumanthu: He holds a M.Tech degree in Structural Engineering JNTUA Anantapur, India. He is currently working as an Assistant professor in Civil Engineering Department GNITC HYD.

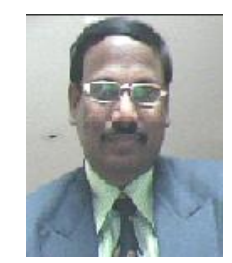

SS.Manugula: He Pursuing $\mathrm{PhD}$ (Civil Engineering) having 21 years of experience (Civil Engg, GIS-Photogrammetry- Remote Sensing) worked with National \& International Clients in various multinational companies. He worked as a Dy. General Manager \& Head of GIS department in Intech Delhi, and also holds the credit of gaining global exposure by working in Abu-Dhabi (UAE) as a client side support international project work.

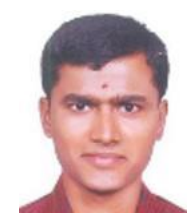

Prathik Kulkarni: He holds a M.Tech degree in Structural Engineering JNTUH Hyderabad, India. He is currently working as an Assistant professor in Civil Engineering Department GNITC HYD 